\title{
VAŽNOST ŠUMARSKE NASTAVE I ZNANOSTI NA SVEUČILIŠTU U ZAGREBU ZA RAZVOJ HRVATSKOG ŠUMARSTVA
}

\section{THE IMPORTANCE OF FORESTRY EDUCATION AND SCIENCE AT THE UNIVERSITY OF ZAGREB FOR THE DEVELOPMENT OF CROATIAN FORESTRY}

Igor ANIĆ

\begin{abstract}
SAŽETAK
Šumarski fakultet Sveučilišta u Zagrebu proslavio je 2018. godine 120. obljetnicu osnutka, jer je 20. listopada 1898. godine na Sveučilištu u Zagrebu počela s radom Šumarska akademija kao prva visokoškolska šumarska institucija u Hrvatskoj i jugoistočnoj Europi. Kontinuitet visokoškolske šumarske nastave na Sveučilištu u Zagrebu zadržao se do danas, kroz razdoblja djelovanja Šumarske akademije (1898.-1919.), Gospodarsko-šumarskog fakulteta (1919.-1946.), Poljoprivredno-šumarskog fakulteta (1946.-1960.) i Šumarskog fakulteta (od 1960.). Cilj je ovoga rada objasniti kako su visokoškolska šumarska nastava i šumarska znanost na Šumarskom fakultetu Sveučilišta u Zagrebu tijekom proteklih 120 godina utjecali na stvaranje i očuvanje šumskog bogatstva Republike Hrvatske kao temeljnog, izvornog, prirodnog, biološki raznolikog i samoobnovljivog. U prilog tomu, naveden je pregled značajnijih postignuća fakulteta i njegovih istaknutih profesora.
\end{abstract}

KLJUČNE RIJEČI: hrvatsko šumarstvo, povijest šumarstva, Sveučilište u Zagrebu, Šumarski fakultet, šumarska nastava, zagrebačka škola uzgajanja šuma

\section{UVOD}

\section{INTRODUCTION}

Gotovo stotinu godina nakon postanka 1765. godine, hrvatsko šumarstvo je u drugoj polovici 19. stoljeća doživjelo preporod. Nizali su se važni događaji koji su omogućili kreiranje organiziranog šumarstva po načelu potrajnosti (Klepac 1997a). Utemeljeno je Hrvatsko-slavonsko šumarsko društvo (1846.), donesen je Zakon o šumama u kojemu je naglašen postulat o potrajnosti prihoda (1852.), u Križevcima je otvorena prva strukovna škola - Gospodarsko-šumarsko učilište (1860.), počelo je izlaziti znanstvenostručno i staleško glasilo Šumarski list (1877.), objavljene su prve knjige o hrvatskim šumama i šumarstvu (Šulek 1866, Köröskenyi 1874, Kesterčanek 1881, 1896, Čordašić 1889), u Zagrebu je izgrađen Šumarski dom (1898.), u Senju je počelo s radom Carsko-Kraljevsko namjesništvo za pošumljenje krasa krajiškoga područja (1878.), u Sv. Mihovilu kraj Senja osnovan je prvi šumski rasadnik (1879.), izrađene su prve osnove gospodarenja za dio šuma Petrove gore (1880.) i za šume Brodske imovne općine (1875.), u Zagrebu je otvorena Šumarska akademija (1898.).

Za razvoj šumarstva posebno je važan osnutak Šumarske akademije, jer je to bila prva visokoškolska šumarska institucija u Hrvatskoj i u jugoistočnoj Europi. Počela je s radom 
20. listopada 1898. godine. $U$ početku je bila prislonjena uz Mudroslovni fakultet Sveučilišta u Zagrebu, čiji je dekan ujedno bio i dekan Šumarske akademije. Već akademske godine 1907./1908. Šumarska akademija samostalno bira svog prvog pročelnika, profesora Frana Žavera Kesterčaneka, a od 17. travnja 1908. ima potpunu upravnu samostalnost (Petračić 1963).

Kontinuitet visokoškolske šumarske nastave na Sveučilištu u Zagrebu zadržao se do danas, kroz razdoblja djelovanja Šumarske akademije (1898.-1919.), Gospodarsko-šumarskog fakulteta (1919.-1946.), Poljoprivredno-šumarskog fakulteta (1946.-1960.) i Šumarskog fakulteta (od 1960.).

U proteklih 120 godina (1898.-2018.) na Šumarskom fakultetu Sveučilišta u Zagrebu diplome je steklo 5304 diplomiranih inženjera šumarstva i magistara inženjera šumarstva, 329 magistara šumarskih znanosti i magistara specijalista šumarstva te 129 doktora šumarskih znanosti (Božić i dr. 2018). Najveći dio tih stručnjaka svoj radni vijek proveo je u hrvatskim šumama koje su izmjerili, kartirali, opisali, analizirali, njegovali, pomladili, zaštitili i očuvali onako kako su to naučili na zagrebačkom Šumarskom fakultetu.

Cilj je ovoga rada objasniti kako su visokoškolska šumarska nastava i šumarska znanost na Šumarskom fakultetu Sveučilišta u Zagrebu u proteklih 120 godina utjecali na stvaranje i očuvanje šumskog bogatstva Republike Hrvatske kao temeljnog, izvornog, prirodnog, biološki raznolikog i samoobnovljivog. U prilog tomu, navest ćemo značajnija postignuća fakulteta i njegovih istaknutih profesora, citirajući literaturu koja bi trebala biti na popisu lektire svakog mladog šumarskog znanstvenika. Radi lakšeg praćenja pregleda, dugu povijest fakulteta smo podijelili u razdoblja prve polovice XX. stoljeća, druge polovice XX. stoljeća i početka XXI. stoljeća.

\section{Neka postignuća Šumarskoga fakulteta Sveučilišta u Zagrebu u prvoj polovici XX. stoljeća - Some achievements of the Faculty of Forestry of the University of Zagreb in the first half of the 20th century}

Hrvatska šumarska visokoškolska nastava i znanost doživjeli su u prvoj polovici XX. stoljeća uzlet koji se može pripisati djelovanju Šumarske akademije u razdoblju 1898.1919. i Gospodarsko-šumarskog fakulteta u razdoblju 1919.-1946. godine.

Među najvažnijim postignućima sveučilišne šumarske nastave i znanosti u to doba u Hrvatskoj, svakako je pojava zagrebačke škole uzgajanja šuma. Zagrebačka škola uzgajanja šuma intenzivno se počela razvijati 14. ožujka 1921. godine, kada je na Gospodarsko-šumarskom fakultetu Sveučilišta u Zagrebu utemeljen Zavod za uzgajanje šuma. Pod zagrebačkom školom uzgajanja šuma podrazumijeva se znanstveni, nastavni i stručni pristup gospodarenju šum- skim ekosustavima kojim se podržavaju: 1. prirodna dinamika i struktura šumskih sastojina, 2. prirodno pomlađivanje šumskih sastojina, 3 . umjetno pomlađivanje šumskih sastojina po načelima prirodnoga pomlađivanja, 4. nekorištenje čistih sječa i očuvanje šumskoga tla od degradacije, 5. intenzivna njega šuma od najranijih razvojnih stadija, 6 . višenamjensko, progresivno i potrajno gospodarenje šumama (Anić 2012).

Do danas se studenti na zagrebačkom Šumarskom fakultetu obrazuju i odgajaju u skladu s tim načelima. Zagrebačka škola uzgajanja šuma i primjena njezinih načela u praktičnom šumarstvu temeljni su razlozi visoke prirodnosti i biološke raznolikosti šumskih ekosustava u Republici Hrvatskoj. Prirodne šume Hrvatske su izvorni proizvod hrvatskog šumarstva, a to znači šumara koji su školovani na zagrebačkom Šumarskom fakultetu, sukladno načelima zagrebačke škole uzgajanja šuma. Zahvaljujući tomu, prirodne šume su postale jedna od temeljnih vrednota hrvatske prirodne riznice.

Drugo važno postignuće toga doba je početak organiziranih i sustavnih znanstvenih istraživanja u šumarstvu, jer je krajem 1921. godine na Gospodarsko-šumarskom fakultetu osnovan Zavod za šumske pokuse. Bila je to prva znanstvena šumarska institucija na području tadašnje države, koja je koordinirala i provodila znanstvena šumarska istraživanja. Uvela je interdisciplinarni pristup u šumarskim istraživanjima, koji se pokazao uspješnim u rješavanju složenih problema funkcioniranja šumskih ekosustava. Rezultati istraživanja Zavoda objavljivani su u prvom šumarskom znanstvenom časopisu Glasnik za šumske pokuse. Do danas su izašle 43 knjige redovitih izdanja i 5 knjiga posebnih izdanja toga časopisa. U prvoj knjizi iz 1926. godine objavljeni su rezultati interdisciplinarnih šumarskih znanstvenih istraživanja uzroka i posljedica sušenja slavonskih hrastovih šuma s početka XX. stoljeća.

Sveučilišni profesori šumarstva na Gospodarsko-šumarskom fakultetu objavili su u prvoj polovici XX. stoljeća prve sveučilišne udžbenike iz temeljnih šumarskih disciplina. Ti su udžbenici odigrali važnu ulogu u obrazovanju šumara i u praktičnom šumarstvu. Spomenut ćemo i neka važnija znanstvena postignuća nekoliko istaknutih profesora toga razdoblja, koja su utjecala na razvoj šumarstva i sliku naših šuma.

Dr. sc. Andrija Petračić (1879.-1958.), redoviti sveučilišni profesor uzgajanja šuma i dendrologije, matičar Šumarskoga fakulteta, dugogodišnji pročelnik Šumarske akademije, prvi dekan Gospodarsko-šumarskog fakulteta Sveučilišta u Zagrebu i utemeljitelj zagrebačke škole uzgajanja šuma, objavio je prve hrvatske sveučilišne udžbenike iz uzgajanja šuma (Petračić 1925, 1931, 1955) kojima je znanost o uzgajanju šuma i zagrebačku školu uzgajanja šuma utvrdio kao temeljne za šumarsku nastavu, znanost i praksu. 
Dr. sc. Antun Levaković (1885.-1955.), redoviti sveučilišni profesor dendrometrije, prvi pročelnik Zavoda za šumske pokuse, jedan od najvećih šumarskih znanstvenika, hrvatsko i svjetsko šumarstvo zadužio je utemeljenjem moderne hrvatske dendrometrije (Levaković 1922), otkrićem formula za "funkciju rastenja drveća" (Levaković 1930), jednadžbom za sastojinsku visinsku krivulju (Levaković 1935), te novijim oblikom frekvencijske funkcije (Levaković 1948, 1952).

Dr. sc. Đuro Nenadić (1876.-1966.), rektor zagrebačkog sveučilišta 1922./1923., redoviti sveučilišni profesor uređivanja šuma i računanja vrijednosti šuma, objavio je udžbenike iz tih područja šumarske znanosti (Nenadić 1922, 1929). Udžbenik Osnove šumarstva (Nenadić 1924) namijenio je „za šumarsko pomoćno osoblje, posjednike šuma i sve one koji sa šumama imaju posla“.

Akademik dr. sc. Aleksandar Ugrenović (1883.-1958.), redoviti sveučilišni profesor iskorištavanja šuma i šumarske politike, pripada najplodnijim hrvatskim šumarskim znanstvenicima, nastavnicima i stručnjacima. Prvi udžbenik iz područja šumarskih tehnika i tehnologija objavio je u šest svezaka (Ugrenović 1931, 1932, 1934, 1935, 1947, 1948). Kao prvi voditelj Arboretuma HAZU u Trstenom, objavio je monografiju o tom spomeniku parkovne arhitekture (Ugrenović 1953).

Akademik dr. sc. Milan Anić (1906.-1968.), redoviti sveučilišni profesor uzgajanja šuma, šumarske fitocenologije i dendrologije, uveo je akademske godine 1940./1941. kolegij Šumarska fitocenologija na Šumarski fakultet u Zagrebu, za koji je napisao prva skripta (Anić 1956, 1960). Zaslužan za dosljednost primjene znanosti o šumskoj vegetaciji u šumarskoj praksi (Anić 1943), čime je utemeljio primjenu načela prirodnosti u uzgajanju šuma.

Šumarski stručnjak Ivo Čeović (1886.-1971.), nastavnik kolegija iz lovstva, zaslužan je za nastavak tradicije sveučilišne nastave iz tog područja koja je počela još 1860 . na Gospodarsko-šumarskom učilištu u Križevcima, a nastavila se na Sveučilištu u Zagrebu, najprije na Šumarskoj akademiji. Napisao je enciklopedijsko djelo Lovstvo (Čeović 1940), koje je poslije istoimene Kesterčanekove knjige s kraja XIX. stoljeća bilo zapravo prvi sistematski prikaz svih područja lovne znanosti i prakse.

Akademik dr. sc. Ivo Pevalek (1893.-1967.), redoviti sveučilišni profesor botanike, istražio je i opisao temeljni fenomen Plitvičkih jezera „kao biodinamički sustav u kojemu vrlo važnu ulogu imaju sedrotvorne biljke i sedrotvorne zajednice"(Pevalek 1938). Zbog tog je otkrića, njemu u čast, uz stazu kod slapa Mali prštavac postavljena spomen-ploča, a Znanstveno-stručni centar na Plitvičkim jezerima nosi njegovo ime.

\section{Neka postignuća Šumarskoga fakulteta Sveučilišta u Zagrebu u drugoj polovici XX. stoljeća - Some achievements of the Faculty of Forestry of the University of Zagreb in the second half of the 20th century}

Drugu polovicu XX. stoljeća obilježava puni procvat hrvatske šumarske visokoškolske nastave i znanosti koji se neposredno odrazio na stanje šuma i razvoj praktičnog šumarstva. On je omogućen organiziranom i kontinuiranom potporom znanstvene djelatnosti u šumarstvu te jedinstvom šumarske znanosti i prakse koja je istraživanja inicirala, podupirala, a rezultate primjenjivala u praksi. Hrvatska šumarska znanost i praksa postali su pravi primjer međusobnog poticanja i snažnog razvoja koji je doveo do poboljšanja stanja šuma Hrvatske u cjelini.

Treba istaknuti kako je u tom razdoblju šumarstvo bilo jedno od malobrojnih područja koja su objavila svoju enciklopediju. Leksikografski zavod u Zagrebu objavio je dva izdanja Šumarske enciklopedije: prvo izdanje u dva toma, 1959.-1963., glavni urednik je akademik Aleksandar Ugrenović, a drugo izdanje u tri toma, 1980.-1987., glavni urednik je prof. dr. sc. Zvonimir Potočić.

U nastavku ćemo navesti neka postignuća šumarske visokoškolske nastave i znanosti koja su ostvarena u tom razdoblju, a koja su neposredno utjecala i na razvoj šumarske prakse.

Razvijaju se nove znanstvene discipline. Tako će dr. sc. Zdenko Tomašegović (1917.-1995.), redoviti sveučilišni profesor geodezije i šumarske fotogrametrije, ostati zapamćen kao pionir fotogrametrije i fotointerpretacije u hrvatskom i u europskom šumarstvu (Tomašegović 1949, 1950, 1956). Dr. sc. Stjepan Bertović (1922.-2001.), redoviti sveučilišni profesor, kreirao je i započeo predavati 1980. godine kolegij Zaštita prirode, čime je pridonio obrazovanju šumara kao stručnjaka koji prirodne šume stvaraju, čuvaju is njima potrajno gospodare. Profesor emeritus dr. sc. dr. h. c. Branimir Prpić (1927.-2012.), redoviti sveučilišni profesor ekologije šuma, šumarske fitobioklimatologije i uređivanja bujica i vodogradnji te prvi hrvatski šumarski ekolog i ekofiziolog, zaslužan je za razvoj ekologije šuma u Hrvatskoj kao znanstvene, nastavne i stručne discipline. U znanstvenom radu posebice se bavio odnosom šumskog drveća prema vodi, zakorijenjivanjem šumskog drveća, fiziološkim srašćivanjem korijenja šumskog drveća, oštećenošću i odumiranjem stabala šumskoga drveća, općekorisnim funkcijama šuma, ekološkim i biološkim obilježjima prašuma u Hrvatskoj. Njegov najveći doprinos hrvatskom šumarstvu je opis općekorisnih funkcija šuma i ustanovljenje kriterija za njihovu procjenu (Prpić 1992). Među najzaslužnijima je za uvođenje naknade za općekorisne funkcije šuma (OKFŠ), čime je neposredno pridonio razvoju šumarstva i domovine u cjelini. Hrvatsko šumarsko društvo i Šu- 
marski fakultet Sveučilišta u Zagrebu objavili su monografiju o znanstvenom, nastavnom i stručnom opusu tog velikana hrvatskog šumarstva (Tikvić, gl. ur., 2018).

Osmišljene su i u šumarsku praksu uvedene nove metode uređivanja šuma. Akademik dr. sc. Dušan Klepac (1917.2006.), redoviti sveučilišni profesor uređivanja šuma, jedan od najvećih hrvatskih šumarskih znanstvenika toga razdoblja, uveo je u hrvatskom šumarstvu novi sistem uređivanja prebornih šuma (Klepac 1961, 1962). Napisao je dva udžbenika (Klepac 1963, 1965), uredio prvu znanstvenu monografiju o hrastu lužnjaku (Klepac, gl. ur., 1996) i objavio monografska djela o našim najvrjednijim šumama (Klepac 1997b, 2000). Na pragu 21. stoljeća, sažeo je spoznaje o šumi, gospodarenju šumskim ekosustavom i uopće odnosu čovjeka i šume u Deset sentenci (Klepac 2004) koje neponovljivo i jednostavno sažimaju dva i pol stoljeća razvoja šumarske znanosti i prakse u Hrvatskoj. Dr. sc. Šime Meštrović (1933.-2018.), redoviti sveučilišni profesor uređivanja šuma te parkiranja i oblikovanja prostora, među prvima je u nas valorizirao ekološke vrijednosti sredozemnih šuma (Meštrović 1976) i potrajnost gospodarenja šumama u Hrvatskoj (Meštrović 1996). Uvelike je pomogao šumarskoj praksi izradbom Priručnika za uređivanje šuma (Meštrović i Fabijanić 1995).

Zagrebačka škola uzgajanja šuma u drugoj polovici XX. stoljeća doživljava punu znanstvenu i praktičnu afirmaciju. To je neposredno utjecalo na očuvanje dostignutog stupnja prirodnosti i biološke raznolikosti hrvatskih šuma. Gospodarenje šumom postaje gospodarenje šumskim ekosustavom, a uzgojni zahvati u šumi se temelje na povezivanju šumskog staništa i šumske fitocenoze sa šumskom sastojinom. Za to je ponajprije zaslužan akademik dr. sc. Milan Anić koji je istraživao složene odnose sastavnica šumskoga ekosustava, posebice kompleksa stanište - biocenoza, s težištem na šumsko drveće, grmlje i prizemno rašće. Ta se njegova težnja zrcali u njegovim skriptama iz uzgajanja šuma (Anić, 1956, 1960, 1963, 1966, 1967). Kao vrstan dendrogeograf, poznavatelj šumske vegetacije, ekologije i biologije šumskog drveća te edifikatorskog značenja šumskog drveća za strukturu i funkcioniranje šumskih zajednica, uveo je njihovo nazivlje po šumskom drveću. Dr. sc. Ivo Dekanić (1919.-1998.), redoviti sveučilišni profesor uzgajanja šuma, prvi je istraživao i povezao dinamiku podzemnih voda u nizinskim šumama s pridolaskom i uspijevanjem šumskih vrsta drveća te potrebnim šumskouzgojnim zahvatima. Definirao je gredu, nizu i baru kao tri temeljna tipa nizinskih šumskih staništa (Dekanić 1962a). Utvrđivanje nizinskog mikroreljefa i njegovo povezivanje s pripadajućim šumskim zajednicama je postao temelj za gospodarenje nizinskim šumama. Posebice se bavio kvalitativnim i kvantitativnim aspektima povećanja proizvodnje šumskih sastojina uz pomoć šumskouzgojnih zahvata njege prorjedom (Dekanić 1980, 1991). Autor je biološko-gospodarske klasifikacije sta- bala u šumskoj sastojini i metode prorjede koja proizilazi iz te klasifikacije (Dekanić 1962b). Idejni je začetnik i prvi realizator koncepcije terenske nastave Šumarskoga fakulteta u Zagrebu uz neposredno uključivanje stručnjaka iz prakse u njezinu održavanju.

Akademik profesor emeritus dr. sc. dr. h. c. Slavko Matić (r. 1938.), redoviti sveučilišni profesor uzgajanja šuma i osnova šumarstva, najznačajniji je promotor zagrebačke škole uzgajanja šuma u šumarskoj znanosti, nastavi i praksi. Afirmirao je u šumarskoj struci opredjeljenje za prirodno pomlađivanje, prirodnu strukturu sastojine te prirodne, raznolike i stabilne šume. U skladu s tim učio je uzgajanju šuma brojne generacije studenata šumarstva i objavio brojne znanstvene radove u kojima je, između ostaloga, dokazao ovisnost prirodnog pomlađivanja preborne sastojine o stanišnim i strukturnim prilikama (Matić 1983), na izvorni način definirao intenzitet prorjeda i metodu prorjeda (Matić 1989a, 1991), sistematizirao i opisao uzgojne postupke (Matić 1989b), istražio prirodno pomlađivanje brojnih šumskih sastojina u Hrvatskoj, a posebice sastojina hrasta lužnjaka u različitim stanišnim uvjetima (Matić 1996), ustanovio optimalni broj biljaka i količinu sjemena za prirodnu i umjetnu obnovu te za pošumljavanje (Matić 1994). Brojnim uzgojnim preporukama neposredno je utjecao na formiranje današnje generacije prirodnih šumskih sastojina. Kao vrstan poznavatelj hrvatskih šuma i šumarstva odlikuje se istančanim osjećajem za analizu njihova stanja i točnim predviđanjem njihova razvoja (Matić 1990).

U drugoj polovici XX. stoljeća intenzivira se vegetacijsko kartiranje šuma Hrvatske. Za to je ponajprije zaslužan dr. sc. Đuro Rauš (1930.-1997.), redoviti sveučilišni profesor šumarske fitocenologije te zaštite prirode i okoliša, autor istoimenih udžbenika (Rauš 1987, 1991) i ponajbolji poznavatelj šumske vegetacije Hrvatske u drugoj polovici XX. stoljeća, posebice nizinskih, poplavnih i ritskih šuma. Razumijevanje njihova postanka, florne i vegetacijske slike te sindinamike zahvaljujemo njegovim ranim istraživanjima u šumskom bazenu Spačva (Rauš 1975) i u podunavskim ritskim šumama (Rauš 1976). Među najvrjednije doprinose koje je ostavio šumarskoj znanosti i praksi spadaju fitocenološka istraživanja i kartiranja šuma te opisi šumskih zajednica koja je obavljao neumorno i nenadmašno širom naše domovine. Uredio je prvu znanstvenu monografiju izdanu nakon osamostaljenja Republike Hrvatske koja cjelovito obrađuje njezino šumsko bogatstvo (Rauš, gl. ur., 1992).

Dr. sc. Ivo Trinajstić (1933.), redoviti sveučilišni profesor šumarske botanike, dugogodišnji istraživač i ponajbolji hrvatski poznavatelj mediteranske flore i vegetacije, definirao je fitogeografsko raščlanjenje šumske vegetacije našeg dijela Mediterana (Trinajstić 1986), što je postao temelj za razumijevanje i organiziranje gospodarenja našim mediteranskim šumama. 
U tom se razdoblju intenzivno razvijaju područja oplemenjivanja šumskog drveća i očuvanja genofonda šumskih vrsta drveća i šuma. Akademik prof. dr. sc. Mirko Vidaković (1924.-2002.), redoviti sveučilišni profesor dendrologije i šumarske genetike s oplemenjivanjem šumskog drveća i prof. dr. sc. Ante Krstinić (1936.-1998.), redoviti sveučilišni profesor šumarske genetike s oplemenjivanjem šumskog drveća, autori su istoimenog sveučilišnog udžbenika (Vidaković i Krstinić 1985). Selekcionirali su šest priznatih klonova stablastih vrba od kojih su četiri danas u uporabi. Mirko Vidaković je autor enciklopedijskog djela Četinjače - morfologija i varijabilnost koje je objavljeno na hrvatskom i engleskom jeziku (Vidaković 1982). Ante Krstinić je svojim znanstvenim radom na oplemenjivanju stablastih vrba stekao reputaciju priznatog salicologa kod nas i u svijetu. Napisao je monografiju o genetici crne topole (Krstinić 1994).

Razvoju dendrometrije i šumarske biometrike u tom su razdoblju posebno pridonijeli redoviti sveučilišni profesori dr. sc. Borivoj Emrović (1913.-1970.) i dr. sc. Ankica Pranjić (r. 1932.). Istraživali su nove metode izmjere šuma, rast $i$ prirast stabala i sastojina. Izradili su znatan broj dvoulaznih i jednoulaznih tablica (regresijskih modela). Pranjić je 1987. ukazala na pogreške u inventuri šuma i njihov utjecaj na rezultate inventure. Dendrokronološkim istraživanjima upozorila je na zbivanja prirodnih pojava u prošlosti naših glavnih vrsta drveća (Pranjić i Lukić 1989, Pranjić 1996). Napisala je udžbenike iz dendrometrije i šumarske biometrike (Pranjić 1986, Pranjić i Lukić 1997).

U području zaštite šuma istaknuto mjesto u tom razdoblju pripada sveučilišnim profesorima, šumarskim entomolozima, fitopatolozima i zaštitarima šuma. Dr. sc. Zlatko Vajda (1901.-1987.), redoviti sveučilišni profesor zaštite šuma i integralne zaštite šuma za koje je napisao sveučilišne udžbenike (Vajda 1974, 1983), istraživao je uzroke masovnoga sušenja pojedinih vrsta šumskoga drveća i šuma. Objasnio je uzroke sušenja bukve na Učki (Vajda 1960) i među prvima dokazao da klimatsko zatopljenje znatno utječe na šume (Vajda 1948). Dr. sc. Milan Androić (1913.-1999.), redoviti sveučilišni profesor šumarske entomologije, uključio je šumarsku entomologiju u sagledavanje složenih odnosa između biotskih i abiotskih čimbenika koji dovode do patologije i poremećaja stabilnosti ekosustava, što je pokazao na primjerima borova četnjaka gnjezdara (Androić 1959) i moljca jelinih iglica (Androić 1960). Dr. sc. Ivan Spaić (1919.-1987.), redoviti sveučilišni profesor zaštite šuma, ostavio je važne priloge šumarskoj entomologiji i ukupnoj problematici zaštite šuma, a dr. sc. Josip Kišpatić (1917.-1994.), redoviti sveučilišni profesor fitopatologije, šumarskoj znanosti i praksi u tom području.

U razvoju visokoškolske šumarske nastave i znanosti lovstva te lovačke prakse važno je spomenuti sveučilišnog profesora dr. sc. Dragutina Andrašića (1909.-1991.), autora brojnih knjiga i priručnika te sveučilišnog udžbenika (Andrašić 1979). Poseban pečat ostavio je poznavanju i razvoju umjetnog uzgoja pernate divljači i obogaćivanju lovišta sitnom pernatom divljači.

U području šumarskih tehnika i tehnologija prijelomni trenutak toga doba bilo je uvođenje jednoručnih motornih pila u šumske radove, čime se posebice bavio dr. sc. Roko Benić (1911.-2000.), redoviti sveučilišni profesor iskorišćivanja šuma, eksploatacije šuma, racionalizacije rada i organizacije rada u drvnoj industriji na Šumarskom fakultetu u Zagrebu te tijekom trinaest godina na Biotehničkom fakultetu u Ljubljani. Zajedno s profesorom Ugrenovićem napisao je udžbenik iz eksploatacije šuma (Ugrenović i Benić 1957). Uredio je Šumarsko-tehnički priručnik koji su koristile brojne generacije studenata i šumarskih praktičara (Benić, gl. ur., 1966).

Dr. sc. Stanko Flögl (1885.-1975.), redoviti sveučilišni profesor gradnje šumskih prometala i teorijske mehanike, napisao je vrijedne sveučilišne udžbenike iz tih područja znanosti (Flögl 1947, 1950, 1955). Dr. sc. Ninoslav Lovrić (1907.-1990.), redoviti sveučilišni profesor šumskih komunikacija, šumskog građevinarstva, uređivanja bujica i vodogradnji te mehanike, pridonio je razvoju hrvatskog šumarstva izradom brojnih glavnih projekata zgrada, šumskih cesta i mostova.

Akademik dr. sc. Mihovil Gračanin (1901.-1981.), redoviti sveučilišni profesor pedologije i ishrane bilja, svojim je udžbenicima za studente agronomije i šumarstva (Gračanin $1946,1947,1951)$ s pravom stekao naslov oca hrvatskog tloznanstva. Dao je golem doprinos pedologiji, biljnoj ekologiji i biljnoj fiziologiji te njihovoj praktičnoj primjeni.

Dr. sc. Branko Kraljić (1915.-1996.), dr. sc. Zvonimir Potočić (1912.-1999.) i dr. sc. Rudolf Sabadi (1928.-2008.), redoviti sveučilišni profesori kolegija iz ekonomike šumarstva, ostavili su u šumarskoj znanosti i praksi pečat razvoju tog područja.

\section{Neka postignuća Šumarskoga fakulteta Sveučilišta u Zagrebu krajem XX. i početkom XXI. stoljeća - Some achievements of the Faculty of Forestry of the University of Zagreb at the end of the 20th century and the beginning of the 21 st century}

Četverogodišnji studij šumarstva izgrađivao se gotovo čitavo stoljeće, počevši od akademske godine 1907./1908., pa do akademske godine 2005./2006. kada je sveučilišna šumarska nastava doživjela korijenite promjene. Tada su se počeli primjenjivati studijski programi usklađeni s načelima Bolonjske deklaracije. Uvedeno je dugo priželjkivano petogodišnje obrazovanje šumarskog inženjera. Međutim, to nije mogao biti željeni integrirani petogodišnji studij, već sustav studiranja ustrojen po načelu $3+2$ ili trogodišnjeg preddiplomskog studija i dvogodišnjeg diplomskog studija. 
Na Šumarskom odsjeku Šumarskoga fakulteta Sveučilišta u Zagrebu uvedena su dva preddiplomska studija i dva diplomska studija: Šumarstvo i Urbano šumarstvo, zaštita prirode i okoliša. Diplomski studij Šumarstvo razdvojen je u dva smjera: Uzgajanje i uređivanje šuma s lovnim gospodarenjem te Tehnike, tehnologije i menadžement u šumarstvu.

Poslijediplomski doktorski studij zadržao je kontinuitet od svojih početaka 1923. godine kada je na Gospodarsko-šumarskom fakultetu obranjena prva disertacija iz šumarske znanosti. Šumarski fakultet Sveučilišta u Zagrebu od akademske godine 2014./2015. izvodi novi poslijediplomski doktorski studij Šumarstvo i drvna tehnologija. Specijalistički šumarski studijski programi ustrojeni su u trajanju od dvije godine u smjerovima Ekološko oblikovanje krajolika, zaštita prirode i hortikultura, Uzgajanje i osnivanje šuma, Šumske tehnike i tehnologije, Lovstvo, Oplemenjivanje i očuvanje genetske raznolikosti šumskog drveća, Šumske prometnice i Uređivanje šuma.

U tom se razdoblju objavljuju suvremeni sveučilišni udžbenici iz šumarske fitocenologije (Vukelić i Rauš 1998, Vukelić 2012), šumarske fitopatologije (Glavaš 1999), dendrologije (Idžojtić 2005, 2009, 2013, 2019), lovnog gospodarenja (Grubešić 2006), šumskih komunikacija (Pičman 2007), šumarske genetike (Kajba i Ballian 2007), bolesti i štetnika urbanih područja (Tomiczek i dr. 2008), statistike (Jazbec 2009), šumarske botanike (Franjić i Škvorc 2010, 2014), upravljanja zaštićenim područjima prirode (Martinić 2010), oplemenjivanja šumskog drveća i očuvanja njegove genetske raznolikosti (Ballian i Kajba 2011), uređivanja šuma (Čavlović 2013), osnivanja šuma (Drvodelić i dr., 2015) i pedologije (Pernar i dr. 2013, Pernar 2017).

Potpora šumarske struke šumarskoj znanosti se nastavila u razdoblju od 1990. do kraja 2013. godine. Omogućila je novoj generaciji nastavnika i znanstvenika na Šumarskom fakultetu u Zagrebu provedbu temeljnih, primijenjenih i razvojnih istraživanja te objavu brojnih i vrijednih znanstvenih djela koja su služila na korist struci. Ta su djela znanstvenoj javnosti i šumarskoj praksi prezentirana na znanstvenim skupovima te u posebnim izdanjima znanstvenih časopisa i znanstvenih zbornika, koji su zapravo periodična izvješća o znanstvenoj djelatnosti: Glasnik za šumske pokuse, posebno izdanje 4, Zagreb, 1993.; Unapređenje proizvodnje biomase šumskih ekosustava, znanstvene knjige I. i II., Zagreb, 1996.; Znanost u potrajnom gospodarenju hrvatskim šumama, Znanstvena knjiga, Zagreb, 2001.; Glasnik za šumske pokuse, posebno izdanje 5, Zagreb, 2006.; Znanstveni skup posvećen 50. godišnjici organizirane suradnje hrvatske šumarske znanosti i struke, Croatian journal of forest engineering, vol. 32/1, Zagreb, 2011. U tim se izdanjima može pronaći na desetke preporuka šumarskoj praksi temeljenih na znanstvenim istraživanjima o postupanju sa šumskim sastojinama u različitim ekološkim, gospodarskim i društvenim prilikama.

Nastavnici Šumarskog fakulteta dali su nemjerljiv doprinos u pisanju i uređivanju dvojezičnih znanstvenih monografija o najvažnijim vrstama drveća i šuma Republike Hrvatske. To su djela enciklopedijske vrijednosti koja su obilježila šumarstvo našega vremena: Šume u Hrvatskoj (Rauš, gl. ur., 1992), Silvae Nostrae Croatiae, (Rauš i Vukelić, gl. ur., 1994), Hrast lužnjak (Quercus robur L.) u Hrvatskoj (Klepac, gl. ur., 1996), Obična jela (Abies alba Mill.) u Hrvatskoj (Prpić, gl. ur., 2001), Obična bukva (Fagus sylvatica L.) u Hrvatskoj (Matić, gl. ur., 2003), Poplavne šume u Hrvatskoj (Vukelić, gl. ur., 2005) i Šume hrvatskog Sredozemlja (Matić, gl. ur., 2011).

Fakultet je bio nositelj projekata nacionalne važnosti, kao što su prva nacionalna inventura šuma Republike Hrvatske (Čavlović 2010) i opis šumskih staništa i šumskih zajednica u Hrvatskoj prema nacionalnoj ekološkoj mreži (Vukelić i dr. 2008). U trilateralnoj suradnji šumarskih fakulteta $u$ Brnu, Beču i Zagrebu objavljeno je na engleskom jeziku enciklopedijsko djelo o poplavnim šumama Europe (Klimo i dr., 2008). Organizirani su svjetski znanstveni kongresi kao, na primjer, kongres iz silvikulture i genetike hrastova, $O A K$ 2000 - Improvement of wood quality and genetic diversity of oaks, u Zagrebu, u svibnju 2000. i 45. kongres iz područja šumarskih tehnika i tehnologija, Forest engineering: concern, knowledge and accountability in today's enviroment, $\mathrm{u}$ Dubrovniku, u listopadu 2012. godine.

Znanstvena izdavačka djelatnost Šumarskoga fakulteta pojačana je 2005. godine kada počinje izlaziti znanstveni časopis Croatian Journal of Forest Engineering, CROJFE. Časopis objavljuje znanstvene radove iz područja šumarskoga inženjerstva. Godine 2007. uvršten je u bibliografsku bazu Web of Science odnosno Science Citation Index Expanded. Pripada među vodeće svjetske časopise iz tog područja šumarske znanosti.

\section{Novi izazovi na početku XXI. stoljeća - New challenges at the beginning of the 21st centry}

Današnji trenutak hrvatskog šumarstva općenito se može ocijeniti nezadovoljavajućim, jer ga pritišću brojni problemi koji se mogu svrstati u tri grupe (Matić i Anić 2015, Anić i Matić 2016): 1) problemi ekološke provenijencije koji su povezani s funkcioniranjem šumskih ekosustava, 2) marginalizacija šumarske struke i ugrožavanje šumarskog inženjera kao temeljnog čimbenika nastanka, optimalnog i potrajnog funkcioniranja šuma, 3) problemi pravne regulative koja posredno ili neposredno ugrožava šume i šumarstvo.

Svaka od tih grupa može se sagledati sa znanstvenog, stručnog, etičkog, pravnog i političkog gledišta. Problemi nisu nastali odjednom. Oni se postupno šire po tkivu hrvatskog šumarstva tijekom posljednjih petnaestak godina. Šumarski 
fakultet nikada nije bio izvan hrvatskih šumarskih tokova, dapače, kao važan dio šumarstva sudjelovao je u njihovu formiranju. Zato je bilo samo pitanje vremena kada će se spomenuti problemi u šumarstvu odraziti i na njegove temeljne zadaće, a to su visokoškolsko obrazovanje i znanstvena istraživanja.

Tako je posljednjih godina zamijećen trend smanjenja interesa mladih ljudi za studiranje na Šumarskom fakultetu. Tu pojavu općenito možemo povezati s padom nataliteta i depopulacijom Hrvatske, posebice ruralnih sredina koje su tradicionalno bile glavni izvor studenata šumarstva. Uz to, u slučaju studija šumarstva mišljenja smo kako je to posljedica krize šumarstva općenito, a posebice one grupe problema koji se odnose na marginalizaciju šumarske struke i ugrožavanje pozicije šumarskog inženjera kao temeljnog čimbenika nastanka, optimalnog i potrajnog funkcioniranja šuma. U slučaju studija urbanog šumarstva mišljenja smo kako je među temeljnim uzrocima nedovoljna prepoznatljivost tog profila na tržištu rada.

Šumarski fakultet, svjestan problema, poduzeo je konkretne korake za popularizaciju studijskih programa u Hrvatskoj. U idućim godinama na sličnim mjerama treba poraditi i u našem okruženju te ih proširiti na specijalističke i doktorske programe. Osim prema potencijalnim studentima, bilo bi dobro poduzeti korake i prema studentima te mladim diplomiranim inženjerima. U suradnji s poslodavcima i strukovnom komorom treba osmisliti programe stipendiranja za nadarene studente, pokušati osigurati pripravnički staž za svakog diplomiranog inženjera i posao za nagrađivane, najvrsnije i stipendirane studente.

Zadaća je fakulteta prilagoditi novim izazovima šumarskog stručnjaka i stručnjaka iz područja urbanog šumarstva, zaštite prirode i okoliša. Šumarski fakultet nakon trinaestgodišnjeg iskustva provedbe nastavnih planova i programa usklađenih s načelima bolonjske reforme treba pokrenuti proces njihova poboljšanja i prilagodbe današnjim izazovima. Pri tome mora iskoristiti prednosti razvoja znanosti o prirodnim šumskim ekosustavima i općenito integriranom i održivom gospodarenju obnovljivim prirodnim izvorima. Zagrebačku školu uzgajanja šuma treba proširiti u hrvatsku školu prirodnog gospodarenja šumskim ekosustavima, a u perspektivi moguće internacionalizacije pojedinih smjerova studija u europsku školu prirodnog gospodarenja šumskim ekosustavima, možda i obnovljivim prirodnim izvorima. Za to imamo sve potrebne preduvjete i komparativne prednosti. U zajedništvu sa šumarskom praksom i strukovnom komorom mogu se osmisliti programi dodatnog osposobljavanja šumarskih praktičara, za što postoje svi preduvjeti.

Intenzitet i opseg znanstvenih istraživanja u hrvatskom šumarstvu općenito su smanjeni, iako je u porastu broj znanstvenih izazova i problema u hrvatskim šumskim eko- sustavima. Negativne promjene stanišnih uvjeta usljed promjene klime, poremećaji u režimu podzemnih i poplavnih voda, degradacija tla nakon šumskih požara i drugih kalamiteta, štete u šumama zbog čestih ektremnih meteoroloških pojava te pojave novih štetnika i biljnih bolesti za posljedicu imaju sve izraženije sušenje stabala i sastojina glavnih vrsta drveća, i općenito sve brojnije probleme u svim šumama, bez obzira na njihovu namjenu. Posebno su ugrožene šume glavnih i najvrjednijih vrsta drveća, hrasta lužnjaka i obične jele, u novije doba i šume poljskog jasena. U provedbi klasičnog regularnog i prebornog gospodarenja šumama sve je više izazova. Te se pojave mogu ublažiti i ukloniti samo stručnim zahvatima u šumskim sastojinama koji se temelje na znanstvenim istraživanjima. Jedinstvo šumarske znanosti i prakse potrebnije je nego ikad, zbog šumarstva i zbog šuma.

Nažalost, strukovno i fondovsko financiranje šumarskih znanstvenih istraživanja kakvo je trajalo do 2013. godine je prekinuto. Danas su sredstva iz nacionalnih izvora namijenjena šumarskim znanstvenim istraživanjima svedena na simboličnu razinu. Sredstvima iz EU fondova i Nacionalne zaklade za znanost obavljaju se temeljna šumarska istraživanja, ali se iz tih izvora ne mogu pokriti sve potrebe za primijenjenim istraživanjima brojnih aktualnih izazova i problema u hrvatskoj šumarskoj praksi i u šumama Hrvatske. Nedostatak takvih šumarskih znanstvenih istraživanja, nažalost, već ima posljedice po šumske ekosustave Republike Hrvatske, a šumarska praksa se često sama muči u traženju rješenja.

Bez znanja i znanosti nema napretka nigdje i nikome. Bio je toga među prvima svjestan i Josip Juraj Strossmayer, kada je 1860. banu Josipu Šokčeviću predao Zakladni list na 50.000 forinti za osnivanje Akademije znanosti i umjetnosti uz popratno pismo u kojemu je napisao: „Narodna je knjiga i glavni plod duha svakoga naroda i glavno promicalo njegova razvitka; pače u nesretnih okolnosti javnoga života jedino sidro, koje ga od propasti čuva." Dodajmo ovome da je hrvatska šumarska povijest pokazala kako jedinstvo šumarske znanosti i prakse dovodi do napretka šumarstva i šuma, a to znači ukupnog napretka domovine. Nije slučajno akademik Dušan Klepac (2004) svojih Deset sentenci završio rečenicom: „Nema napretka u šumarstvu bez znanosti i bez kulture". Citirane rečenice Strossmayera i Klepca danas su itekako aktualne.

\section{ZAKLJUČAK} CONCLUSION

Šumarski fakultet Sveučilišta u Zagrebu proslavio je 2018. godine 120. obljetnicu osnutka, jer je 20. listopada 1898. godine na Sveučilištu u Zagrebu počela s radom Šumarska akademija kao prva visokoškolska šumarska institucija u Hrvatskoj i u jugoistočnoj Europi. 
Kontinuitet visokoškolske šumarske nastave na Sveučilištu u Zagrebu se zadržao do danas, kroz razdoblja djelovanja Šumarske akademije (1898.-1919.), Gospodarsko-šumarskog fakulteta (1919.-1946.), Poljoprivredno-šumarskog fakulteta (1946.-1960.) i Šumarskog fakulteta (od 1960.).

U razvoju šumarske nastave i znanosti na Sveučilištu u Zagrebu tijekom proteklih 120 godina, mogu se razdvojiti tri razdoblja: razdoblje prve polovice XX. stoljeća, razdoblje druge polovice XX. stoljeća te razdoblje početka XXI. stoljeća.

U prvoj polovici XX. stoljeća hrvatska šumarska visokoškolska nastava i znanost doživjeli su uzlet koji se može pripisati djelovanju Šumarske akademije i Gospodarsko-šumarskog fakulteta. Među najvažnijim doprinosima sveučilišne šumarske nastave i znanosti u Hrvatskoj su pojava i razvoj zagrebačke škole uzgajanja šuma te početak organizirnih i sustavnih šumarskih znanstvenih istraživanja.

Drugu polovicu XX. stoljeća obilježava puni procvat hrvatske šumarske visokoškolske nastave i znanosti koji se neposredno odrazio na stanje šuma i razvoj praktičnog šumarstva. U tom su razdoblju hrvatsko šumarstvo, znanost i praksa, postali pravi primjer međusobnog poticanja i snažnog razvoja, koji je doveo do poboljšanja stanja šuma Hrvatske u cjelini. U šumarskoj praksi se afirmiraju načela zagrebačke škole uzgajanja šuma, opredjeljenje za prirodno pomlađivanje, prirodnu strukturu sastojine te prirodne, raznolike i stabilne šume.

Taj se trend nastavio i tijekom XXI. stoljeća, ali je novo doba istodobno donijelo velike promjene i izazove u visokoškolskoj šumarskoj nastavi i znanosti. Kriza šumarstva koja se postupno razvijala u posljednjih petnaestak godina odrazila se na temeljne djelatnosti fakulteta: visokoškolsku nastavu i znanost.

Šume su najraširenije i najznačajnije kopneno prirodno dobro Republike Hrvatske. Posla u šumarstvu i urbanom šumarstvu, zaštiti prirode i okoliša ima puno i bit će ga sve više. Sve je veći broj izazova i problema u hrvatskim šumskim ekosustavima. S druge strane, sve je manje radne snage u šumarstvu. Zbog toga nema razloga za krizu jednog od najprirodnijih i najstarijih studija na Sveučilištu u Zagrebu. Upravo suprotno, šumarski stručnjaci imaju itekakvu perspektivu u današnjim ekološkim, gospodarskim i društvenim prilikama. Zadaća je fakulteta prilagoditi novim izazovima sebe i svoje temeljne proizvode, stručnjake za gospodarenje šumskim ekosustavima.

Šumarska praksa i šumarska znanost moraju zajednički djelovati, uostalom, kao i kroz dugu šumarsku povijest. Samo će tako osigurati prosperitet u skladu s definicijom šumarstva kao znanosti, struke i umijeća gospodarenja i očuvanja šumskih ekosustava za trajnu dobrobit čovjeka, društva, okoliša i gospodarstva.

\section{LITERATURA}

\section{REFERENCES}

- Andrašić, D., 1979: Zoologija divljači i lovna tehnologija. Sveučilišna naklada Liber, Zagreb, 1-392.

- Androić, M., 1959: Borov četnjak gnjezdar (Cnethocampa pityocampa Schiff.) - biološko-ekološka studija. Glasnik za šumske pokuse, 13: 351-460.

- Androić, M., 1960: Argyresthia fundella - moljac jelinih iglica - uročnik sušenja jele u Gorskom kotaru. Šumarski list, 84(7-8): 203-215.

- Anić, I., 2012: Raznolikost i prirodnost šuma u Hrvatskoj. U: S. Matić, F. Tomić, I. Anić (ur.), Zbornik radova okruglog stola Šume, tla i vode - neprocjenjiva prirodna bogatstva Hrvatske, Hrvatska akademija znanosti i umjetnosti, Zagreb, str. 17-35.

- Anić, I., S. Matić, 2016: Šume i šumarstvo Republike Hrvatske. U: V. Neidhardt (ur.), Hrvatska prirodna bogatstva, Hrvatska akademija znanosti i umjetnosti, Zagreb, str. 167-177.

- Anić, M., 1943: Sociologija bilja i njena važnost za hrvatsko šumarstvo. Šumarski list, 67 (10-12): 297-309.

- Anić, M., 1956: Šumarska fitocenologija, I. dio. Skripta, Šumarski fakultet Sveučilišta u Zagrebu, str. 1-54.

- Anić, M., 1960: Šumarska fitocenologija, II. dio. Skripta, Šumarski fakultet Sveučilišta u Zagrebu, str. 1-117.

- Anić, M., 1963: Morfologija šuma. Skripta, Šumarski fakultet Sveučilišta u Zagrebu, str. 1-29.

- Anić, M., 1966: Geografija šumskog drveća i šuma. Šumarski fakultet Sveučilišta u Zagrebu, str. 1-114.

- Anić, M., 1967: Ekologija šumskog drveća i šuma. Skripta, Šumarski fakultet Sveučilišta u Zagrebu, str. 1-208.

- Ballian, D., D. Kajba, 2011: Oplemenjivanje šumskog drveća i očuvanje njegove genetske raznolikosti. Šumarski fakultet Univerziteta u Sarajevu i Šumarski fakultet Sveučilišta u Zagrebu, str. 1-299.

- Benić, R. (gl. ur.), 1966: Šumarsko-tehnički priručnik. Nakladni zavod Znanje, Zagreb, str. 1-568.

- Čeović, I., 1940: Lovstvo. Zagreb, str. 1-445.

- Čavlović, J., 2010: Prva nacionalna inventura šuma Republike Hrvatske. Ministarstvo poljoprivrede, šumarstva i vodnoga gospodarstva, Šumarski fakultet Sveučilišta u Zagrebu, Zagreb, str. 1-300.

- Čavlović, J., 2013: Osnove uređivanja šuma. Šumarski fakultet Sveučilišta u Zagrebu, str. 1-322.

- Čordašić, F., 1889: Nauka o sađenju i gajenju šuma. Tiskarski i litografijski zavod C. Albrechta u Zagrebu, str. 1-212.

- Dekanić, I., 1962a: Utjecaj podzemne vode na pridolazak i uspijevanje šumskog drveća u posavskim šumama kod Lipovljana. Glasnik za šumske pokuse, 15: 5-102.

- Dekanić, I., 1962b: Biološki i gospodarski faktori njegovanja sastojina. Šumarski list, 86 (11-12): 398-402.

- Dekanić, I., 1980: Način i intenzitet proreda u šumi hrasta lužnjaka i običnog graba. Slavonska šuma, Vinkovci, str. 1-120.

- Dekanić, I., 1991: Utjecaj strukture na njegu sastojina proredom u šumi hrasta lužnjaka i običnog graba (Querco roboris-Carpinetum Illyricum Anić). Hrvatska akademija znanosti i umjetnosti, Centar za znanstveni rad Vinkovci, Vinkovci, str. 1-147.

- Drvodelić, D., T. Jemrić, M. Oršanić, 2015: Oskoruša: važnost, uporaba i uzgoj. Sveučilište u Zagrebu, Šumarski fakultet, str. 1-182. 
- Flögl, S., 1947: Osnovna građevna mehanika. Poljoprivredni nakladni zavod, Zagreb, 1-429.

- Flögl, S., 1950: Gradnja mostova na šumskim putovima i prugama. Nakladni zavod Hrvatske, Zagreb, 1-448.

- Flögl, S., 1955: Gradnja šumskih putova i pruga. Poljoprivredni nakladni zavod, Zagreb, 1-525.

- Glavaš, M., 1999: Gljivične bolesti šumskoga drveća. Šumarski fakultet Sveučilišta u Zagrebu, str. 1-281.

- Gračanin, M., 1946: Pedologija (tloznanstvo). I. dio, Geneza tala, Poljoprivredni nakladni zavod, Zagreb, str. 1-147.

- Gračanin, M., 1947: Pedologija (tloznanstvo). II. dio, Fiziografija tala, Poljoprivredni nakladni zavod, Zagreb, str. 1-234.

- Gračanin, M., 1951: Pedologija (tloznanstvo). III. dio, Sistematika tala, Školska knjiga, Zagreb, str. 1-298.

- Grubešić, M., 2006: Uzgojna područja za jelena, divokozu i divlju svinju na području Republike Hrvatske. Sveučilište u Zagrebu, Šumarski fakultet, str. 1-96.

- Idžojtić, M., 2005: Listopadno drveće i grmlje u zimskom razdoblju. Šumarski fakultet Sveučilišta u Zagrebu, str. 1-256.

- Idžojtić, M., 2009: Dendrologija - List. Šumarski fakultet Sveučilišta u Zagrebu, str. 1-904.

- Idžojtić, M., 2013: Dendrologija - Cvijet, češer, plod, sjeme. Šumarski fakultet Sveučilišta u Zagrebu, str. 1-672.

- Idžojtić, M., 2019: Dendrology: Cones, Flowers, Fruits and Seeds. Elsevier - Academic Press, London, San Diego, Cambridge, Oxford, str. 1-767.

- Jazbec, A., 2009: Osnove statistike. Šumarski fakultet Sveučilišta u Zagrebu, str. 1-149.

- Kajba, D., D. Ballian, 2007: Šumarska genetika. Šumarski fakultet Sveučilišta u Zagrebu, str. 1-283.

- Kesterčanek, F., 1881: Dendrometrija. Naklada dalm. hrv. slav. vlade, Zagreb, str. 1-135.

- Kesterčanek, F., 1896: Lovstvo. Priručnik za lovce i poučnik za nadzirače lova, Zagreb, str. 1-350.

- Klepac, D., 1961: Novi sistem uređivanja prebornih šuma. Poljoprivredno-šumarska komora, Zagreb, str. 1-46.

- Klepac, D., 1962: Novi sistem uređivanja prebornih šuma, dodatak. Poljoprivredno-šumarska komora, Zagreb, str. 1-24.

- Klepac, D., 1963: Rast i prirast šumskih vrsta drveća i sastojina. Nakladni zavod Znanje, Zagreb, str. 1-298.

- Klepac, D., 1965: Uređivanje šuma. Nakladni zavod Znanje, Zagreb, str. 1-341.

- Klepac, D. (gl. ur.), 1996: Hrast lužnjak (Quercus robur L.) u Hrvatskoj. Hrvatska akademija znanoasti i umjetnosti, Centar za znanstveni rad u Vinkovcima i Hrvatske šume p. o. Zagreb, Zagreb - Vinkovci, str. 1-559.

- Klepac, D., 1997a: Hrvatsko šumarstvo u drugoj polovici XIX. stoljeća. Šumarski list, 121 (3-4): 115-126.

- Klepac, D., 1997b: Iz šumarske povijesti Gorskoga kotara u sadašnjost. Hrvatske šume p. o. Zagreb, str. 1-236.

- Klepac, D., 2000: Najveća cjelovita šuma hrasta lužnjaka u Hrvatskoj - Spačva. Hrvatska akademija znanoasti i umjetnosti, Zagreb, str. 1-116.

- Klepac, D., 2004: Nekoliko misli u prilog izradbe kodeksa o gospodarenju prirodnim šumama. Šumarski list, 128 (7-8): 445.

- Klimo, E., H. Hager, S. Matić, I. Anić, J. Kulhavy (ur.), 2008: Floodplain forests of the temperate zone of Europe. Lesnicka prace, str. 1-623.
- Köröskenyi, V., 1873: Obće šumarstvo. Tisak Dragutina Albrechta, Zagreb, str. 1 - 166.

- Krstinić, A., 1994: Genetics of Black Alder (Alnus glutinosa L. Gaertn. ). Annales Forestales, 19 (2): 33-72.

- Levaković, A., 1922: Dendrometrija ili nauka o izmjeri drvlja. Hrvatsko šumarsko društvo, Zagreb, str. 1-341.

- Levaković, A., 1930: Jedna nova jednadžba rastenja. Spomenica vinkovačke gimnazije, Osijek, str. 120-130.

- Levaković, A., 1935: Analitički izraz za sastojinsku visinsku krivulju. Glasnik za šumske pokuse, 4: 283-310.

- Levaković, A., 1948: O analitičkom izražavanju sastojinske strukture. Glasnik za šumske pokuse, 9: 293-366.

- Levaković, A., 1952: O analitičkom izražavanju sastojinske strukture. Dodatak. Glasnik za šumske pokuse, 10: 5-24.

- Martinić, I., 2010: Upravljanje zaštićenim područjima prirode: planiranje, razvoj i održivost. Šumarski fakultet Sveučilišta u Zagrebu, str. 1-367.

- Matić, S., 1983: Utjecaj ekoloških i strukturnih činilaca na prirodno pomlađivanje prebornih šuma jele i bukve u Gorskom kotaru. Glasnik za šumske pokuse, 21: 223-388.

- Matić, S., 1989a: Intenzitet prorede i njegov utjecaj na stabilnost, proizvodnost i pomlađivanje sastojina hrasta lužnjaka. Glasnik za šumske pokuse, 25: 261-278.

- Matić, S., 1989b: Uzgojni radovi u prirodnim sastojinama i mogućnost njihovog normiranja. Šumarski list, 113 (1-2): 3953.

- Matić, S., 1990: Šume i šumarstvo Hrvatske - jučer, danas, sutra. Glasnik za šumske pokuse, 26: 33-56.

- Matić, S., 1991: Njega šuma proredom. Hrvatske šume p. o. Zagreb, Uprava šuma Koprivnica, Zagreb, str. 1-45.

- Matić, S., 1994: Prilog poznavanju broja biljaka i količine sjemena za kvalitetno pomlađivanje i pošumljavanje. Šumarski list 138 (3-4): 71-79.

- Matić, S., 1996: Uzgojni radovi na obnovi i njezi sastojina hrasta lužnjaka. U: D. Klepac (ur.), Hrast lužnjak (Quercus robur L.) u Hrvatskoj, HAZU, Centar za znanstveni rad u Vinkovcima i Hrvatske šume p. o. Zagreb, Zagreb - Vinkovci, str. 167-212.

- Matić, S. (gl. ur.), 2003: Obična bukva (Fagus sylvatica L.) u Hrvatskoj. Akademija šumarskih znanosti, Zagreb, str. 1-855.

- Matić, S. (gl. ur.), 2011: Šume hrvatskoga Sredozemlja. Akademija šumarskih znanosti, Zagreb, str. 1-740.

- Matić, S. I. Anić, 2015: Hrvatsko šumarstvo u današnjim gospodarskim i ekološkim uvjetima. U: S. Matić, F. Tomić, I. Anić (ur.), Zbornik radova znanstvenog skupa Proizvodnja hrane i šumarstvo - temelj razvoja istočne Slavonije. Hrvatska akademija znanosti i umjetnosti, Zagreb, str. 41-61.

- Meštrović, Š., 1976: Utjecaj borovih kultura na čistoću zraka u Kliško-solinskom bazenu. Glasnik za šumske pokuse, 20: 231297.

- Meštrović, Š., G. Fabijanić, 1995: Priručnik za uređivanje šuma. Ministarstvo poljoprivrede i šumarstva Hrvatske, Zagreb, $1-416$.

- Meštrović, Š., 1996: Potrajnost gospodarenja šumama u hrvatskoj. U: S. Sever (gl. ur.), Zaštita šuma i pridobivanje drva, Znanstvena knjiga, Šumarski fakultet Sveučilišta u Zagrebu i Šumarski institut, Jastrebarsko, str. 143-148.

- Nenadić, Đ., 1922: Računanje vrijednosti šuma i šumska statika. Naklada Hrvatskog šumarskog društva, Zagreb, str. 1-412.

- Nenadić, Đ., 1924: Osnovi šumarstva. Zaklada tiskare Narodnih novina, Zagreb, str. 1-416. 
- Nenadić, Đ., 1929: Uređivanje šuma. Zaklada tiskare Narodnih novina, Zagreb, str. 1-302.

- Pernar, N., D. Bakšić, I. Perković, 2013: Terenska i laboratorijska istraživanja tla, priručnik za uzorkovanje i analizu. Šumarski fakultet Sveučilišta u Zagrebu, str. 1-192.

- Pernar, N., 2017: Tlo - nastanak, značajke, gospodarenje. Šumarski fakultet Sveučilišta u Zagrebu, str. 1-799.

- Petračić, A., 1925: Uzgajanje šuma, I. svezak. Vlastita naklada, Zagreb, str. 1-307.

- Petračić, A., 1931: Uzgajanje šuma, II. svezak. Vlastita naklada, Zagreb, str. 1-307.

- Petračić, A., 1955: Uzgajanje šuma, ekološki osnovi. Poljoprivredni nakladni zavod, Zagreb, str. 1-171.

- Petračić, A., 1963: Šumarska akademija 1898.-1919. U: Neidhardt, N., M. Androić (ur.), Šumarska nastava u Hrvatskoj 1860.-1960., Šumarski fakultet Sveučilišta u Zagrebu, Zagreb, str. $57-112$.

- Pevalek, I., 1938: Biodinamika Plitvičkih jezera i njena zaštita. Zaštita prirode, 1: 40-61.

- Pičman, D., 2007: Šumske prometnice. Šumarski fakultet Sveučilišta u Zagrebu, str. 1-460.

- Pranjić, A., 1986: Šumarska biometrika. Šumarski fakultet Sveučilišta u Zagrebu, 1-143.

- Pranjić, A., 1987: Pouzdanost rezultata izmjere šuma. Glasnik za šumske pokuse, pos. izd. 3, str. 161-175.

- Pranjić, A. N. Lukić, 1989: Prirast stabala hrasta lužnjaka kao indikator stanišnih promjena. Glasnik za šumske pokuse, 25: 79-94.

- Pranjić, A., 1996: Dendrokronologija hrasta lužnjaka. U: D. Klepac (gl. ur.), Hrast lužnjak (Quercus robur L.) u Hrvatskoj, Hrvatska akademija znanosti i umjetnosti, Centar za znanstveni rad u Vinkovcima i Hrvatske šume p. o. Zagreb, Zagreb - Vinkovci, str. 299-305.

- Pranjić, A., N. Lukić, 1997: Izmjera šuma. Šumarski fakultet Sveučilišta u Zagrebu, str. 1-405.

- Prpić, B., 1992: O vrijednosti općekorisnih funkcija šume. Šumarski list, 116 (6-8): 301-312.

- Prpić, B. (gl. ur.), 2001: Obična jela (Abies alba Mill.) u Hrvatskoj. Akademija šumarskih znanosti, Zagreb, str. 1-895.

- Rauš, Đ., 1975: Vegetacijski i sinekološki odnosi šuma u bazenu Spačva. Glasnik za šumske pokuse, 18: 225-344.

- Rauš, Đ., 1976: Vegetacija ritskih šuma dijela Podunavlja od Aljmaša do Iloka. Glasnik za šumske pokuse, 19: 5-75.

- Rauš, Đ., 1987: Šumarska fitocenologija. Sveučilišna naklada Liber, Zagreb, str. 1-313.

- Rauš, Đ., 1991: Zaštita prirode i čovjekovog okoliša. Sveučilišna naklada, Zagreb, str. 1-254.

- Rauš, Đ. (gl. ur.), 1992: Šume u Hrvatskoj. Šumarski fakultet Sveučilišta u Zagrebu i Hrvatske šume p. o. Zagreb, Zagreb, str. $1-340$.

- Rauš, Đ., J. Vukelić (gl. ur.), 1994. Silvae nostrae Croatiae. Ministarstvo poljoprivrede i šumarstva Republike Hrvatske, Zagreb, str. 1-327.

- Šulek, B., 1866: Korist i gojenje šumah osobito u trojednoj Kraljevini. Narodna tiskara Ljudevita Gaja, Zagreb, str. 1-219.

- Tikvić, I. (gl. ur.), 2018: Branimir Prpić - ekologija šuma i šumarstvo. Hrvatsko šumarsko društvo i Šumarski fakultet Sveučilišta u Zagrebu, Zagreb, str. 1-433.
- Tomašegović, Z., 1949: Sadašnje mogućnosti fotogrametrije u šumarstvu. Šumarski list, 73 (6-7): 215-220.

- Tomašegović, Z., 1950: Osnovi fotogrametrije i fototaksacije. U: N. Neidhardt, Osnovi geodezije, Zagreb, str. 182-223.

- Tomašegović, Z., 1956: O pouzdanosti aerofototaksacije za neke dendrometrijske potrebe šumskog gospodarstva. Glasnik za šumske pokuse, 12: 167-224.

- Tomiczek, C., D. Diminić, T. Cech, B. Hrašovec, H. Krehan, M. Pernek, B. Perny, 2008: Bolesti i štetnici urbanog drveća. Šumarski institut, Jastrebarsko i Šumarski fakultet Sveučilišta u Zagrebu, str. 1-382.

- Trinajstić, I., 1986: Fitogeografsko raščlanjenje šumske vegetacije istočnojadranskog sredozemnog područja - polazna osnovica $\mathrm{u}$ organizaciji gospodarenja mediteranskim šumama. Glasnik za šumske pokuse, pos. izd., 2: 53-67.

- Ugrenović, A., 1931: Iskorišćavanje šuma. Tisak Nadbiskupske tiskare, Zagreb, str. 1-225.

- Ugrenović, A., 1932: Tehnologija drveta. Vlastita naklada, Zagreb, str. 1-293.

- Ugrenović, A., 1934: Tehnika trgovine drvetom, I. dio. Ministarstvo industrije i rudarstva, Zagreb, str. 1-276.

- Ugrenović, A., 1935: Tehnika trgovine drvetom, II. dio. Tisak Nadbiskupske tiskare, Zagreb, str. 1-592.

- Ugrenović, A., 1947: Kemijsko iskorišćavanje i konzerviranje drveta. Redakcija Ministarstva industrije i rudarstva NR Hrvatske, Zagreb, str. 1-244.

- Ugrenović, A., 1948: Upotreba drveta i sporednih produkata šume. Nakladni zavod Hrvatske, str. 1-414.

- Ugrenović, A., 1953: Trsteno, Arboretum i stanica Instituta za eksperimentalno šumarstvo Jugoslavenske akademije. Jugoslavenska akademija znanosti i umjetnosti, Zagreb, str. 1-215.

- Ugrenović, A. R. Benić, 1957: Eksploatacija šuma. Poljoprivredni nakladni zavod, Zagreb, str. 1-477.

- Vajda, Z., 1948: Utjecaj klimatskih kolebanja na sušenje hrastovih posavskih i donjoposavskih nizinskih šuma. Institut za šumarska istraživanja Minisarstva šumarstva NR Hrvatske, Zagreb, str. 1-140.

- Vajda, Z., 1960: Ekstremna klimatska stanja i sušenje bukovih šuma na Učki od 1947. do 1953. Glasnik za šumske pokuse, 14: 5-34.

- Vajda, Z., 1974: Nauka o zaštiti šuma. Školska knjiga, Zagreb, str. $1-482$.

- Vajda, Z., 1983: Integralna zaštita šuma. Sveučilišna naklada Liber, Zagreb, str. 1-253.

- Vidaković, M., 1982: Četinjače - morfologija i varijabilnost. Jugoslavenska akademija znanosti i umjetnosti i Sveučilišna naklada Liber, Zagreb, str. 1-710.

- Vidaković, M., A. Krstinić, 1985: Genetika i oplemenjivanje šumskog drveća. Sveučilišna naklada Liber, Zagreb, str. 1-505.

- Vukelić, J. Đ. Rauš, 1998: Šumarska fitocenologija i šumske zajednice u Hrvatskoj. Šumarski fakultet Sveučilišta u Zagrebu, str. 1-310.

- Vukelić, J. (gl. ur.), 2005: Poplavne šume u Hrvatskoj. Akademija šumarskih znanosti, Zagreb, str. 1-455.

- Vukelić, J., S. Mikac, D. Baričević, D. Bakšić, R. Rosavec, 2008: Šumska staništa i šumske zajednice u Hrvatskoj, Nacionalna ekološka mreža. Državni zavod za zaštitu prirode, Zagreb, str. $1-263$.

- Vukelić, J., 2012: Šumska vegetacija Hrvatske. Šumarski fakultet Sveučilišta u Zagrebu, str. 1-403. 


\section{SUMMARY}

This paper explores the influence of higher forestry education and forestry science at the Faculty of Forestry of the University of Zagreb on the formation and preservation of forest wealth in the Republic of Croatia during the past 120 years as the basic, authentic, self-renewable, biologically diverse and distinctly natural element. In order to do so, we shall provide a survey of some significant achievements of the faculty and its distinguished professors by citing examples of important textbooks and scientific papers.

In the year 2018, the Faculty of Forestry in Zagreb marked the 120th anniversary of its establishment. It was on October 20th, 1898, that the Academy of Forestry was founded within the University of Zagreb as the first higher forestry institution in Croatia and in the south-east of Europe.

The continuity of higher forestry education at the University of Zagreb has been retained to date through the periods of activity of the Academy of Forestry (1898 - 1919), the Faculty of Agriculture and Forestry (1919-1946), the Agricultural-Forestry Faculty (1946 - 1960) and the Faculty of Forestry (1960 - to date).

Three characteristic periods can be singled out in the development of forestry education and science at the Faculty of Forestry in Zagreb in the course of 120 years: the first half of the 20th century, the second half of the 20th century and the first half of the 21 st century.

The first half of the 20th century witnessed a surge in the Croatian forestry, which can primarily be attributed to the development of higher forestry education and science at the Academy of Forestry and the Faculty of Agriculture and Forestry of the University of Zagreb. Among the most important contributions of university forestry education and science in Croatia are the establishment of the Zagreb School of Silviculture and the beginnings of organized and systematic scientific research in forestry.

The second half of the 20th century is characterized by the blossoming of higher forestry education and science in Croatia, which had a direct impact on the condition of forests and the development of practical forestry. During this period, the Croatian forestry, science and practice became an outstanding example of mutual cooperation and powerful development, which brought about an improvement in the condition of forests in Croatia as a whole. The forestry practice firmly adhered to the principles of the Zagreb School of Silviculture, an orientation towards natural regeneration, natural stand structure, and natural, diverse and stable forests.

This trend has continued in the 21st century. The new age has given rise to vast changes and challenges in higher forestry education and science. The crisis of forestry, which has gradually been evolving over the past fifteen years, has had its repercussions on the basic activity of the Faculty: higher education and science. Today, the Faculty of Forestry is confronted with two serious challenges: lesser interest of young people in studying and a reduced intensity and scope of scientific research in forest ecosystems. There are no objective reasons for either of the above, however. Forests are the most widespread and the most important natural wealth in the continental part of the Republic of Croatia. There are currently a large number of job openings in forestry and urban forestry, as well as in nature and environment protection, and this trend will continue to rise in the future. The Croatian forest ecosystems are facing growing numbers of challenges and problems. On the other hand, there are fewer and fewer workers in forestry. In view of this, there is no reason for crisis in one of the most natural and oldest studies at the University of Zagreb. On the contrary, forestry experts have splendid prospects in today's ecological, economic and social conditions. The task of the Faculty is to adjust itself and its basic products, experts in the management of forest ecosystems of the Republic of Croatia, to new challenges.

Forestry practice and forestry science must work together, just as they have done throughout the long forestry history. Only be doing so will their development be ensured in accordance with the definition: forestry is a science, profession and art of managing and preserving forest ecosystems for the permanent benefit of man, society, environment and economy.

KEY WORDS: Croatian forestry, history of forestry, University of Zagreb, Faculty of Forestry, forestry education, Zagreb School of Silviculture 